\title{
PRELIMINARY PHYTOCHEMICAL SCREENING OF BIOACTIVE CHEMICALS IN SUNFLOWER (Tithonia diversifolia) ROOTS
}

\author{
*Ahmed, S. $\mathrm{O}^{1}$ and Bamigboye Samson. $\mathrm{O}^{2}$ \\ ${ }^{1}$ Kano State University of Science and Technology, Wudil, Nigeria \\ ${ }^{2}$ Department of Animal Science, University of Abuja, Nigeria \\ Corresponding Author: Ahmedsani9090@gmail.com
}

\begin{abstract}
Plants are the most available sources of nutrients and phytochemicals; they have also played an important role in the development of drugs and treatment of various ailments in many countries. Therefore, this study was carried out to ascertain the preliminary phytochemical screening of bioactive chemicals in wild sunflower (Tithonia diversifolia) root. The solvents used for extraction includes: petroleum ether, methanol and distilled water. Results revealed that tannins, flavonoids, phenols, steroids, glycosides, carbohydrates and protein were present in the aqueous extract; only saponins were not detected in the sample. Methanol and petroleum ether follow similar pattern as tannins, flavonoids, phenols, steroids, glycosides, saponins carbohydrates and protein were all present in the sample. It was concluded that the extract contained several bioactive chemicals which could confer it the ability to have therapeutic or pharmacological effects on human and animals.
\end{abstract}

Keywords: Tithonia diversifolia, phytochemicals, nutrients, chemicals.

\section{Introduction}

Tithonia diversifolia (Hemsley) A. Gray is a representative of the sunflower family (Asteraceae) and it is popularly called Tree Marigold, Mexican Sunflower, Japanese Sunflower (Kawini et al., 2017). The plant is about $2.5 \mathrm{~m}$ high, bushy and much branched. It reproduces from seeds and through vegetative re-growth of the basal stem when the plant is cut. The stem is quadrangular, spirally-ridged, pubescent below and glabrous above. The leaves are simple, alternate, lobed and of about 5-15 cm long and $3.5-6 \mathrm{~cm}$ broad. It is dark green, toothed and wedged shaped at the base (Akobundu and Agyakwa, 1997). Flower heads are yellow, large, daisy-like, on peduncles 7 to 30 centimeters long. Petals are 7 to 15, bright yellow, 4 to 7 centimeters long and 9 to 16 millimeters wide, with three small teeth at the tips (Oyewole et al., 2008; Chukwuka et al., 2007). Center of the flower heads have about 80 to 120 tiny tubular florets surrounded by several rows of green bracts. Seeds are 4 to 8 millimeters long and topped with a ring of scales and two awns, blackish in color, and somewhat four-angled (Umar et al., 2015; Tagne et al., 2018).

Phytochemical screening of flowers yielded phenolic compounds (tannins, flavonoids, and total phenols), with no alkaloids and saponins (Robson et al., 2014; Wahyuningsih et al., 2015). Proximate analysis of stems yielded moisture $20.6 \%$, total ash $6.55 \%$, acid insoluble ash $0.33 \%$, and sulphated ash $14.0 \%$. Nutrition analysis yielded protein $9.62 \%$, fat $4.21 \%$, fiber $15.82 \%$, and carbohydrate $70.35 \%$ (Essiett and Akpan, 2013). Scientific studies have suggested antimicrobial, analgesic, anti-inflammatory, antidiabetic, chemopreventive, hepatoprotective, repellent, antimalarial, anti-diarrheal, antiemetic, radical scavenging, phytoremediative, biolarvicidal properties of the plant parts (Olutobi and Olasupo, 2012) and plant (stem, leaf and roots) has been traditionally used for the treatment of snake bites, malaria, diabetes, sore throat, wounds and constipation (Martinez et al., 2008; Doughari, 2012).

The objective of this study was to do a preliminary phytochemical screening of bioactive chemicals in sunflower (Tithonia diversifolia) roots.

Experimental Site

\section{Materials and methods}

The study was carried out at the department of biochemistry, Kano State University of Science and Technology, Wudil, Kano State.

Sample collection and processing

Fresh roots of wild sunflower (Tithonia diversifolia) were harvested from the institutions teaching and research farm. The species were identified and authenticated at the herbarium department of crop science, Kano State University of Science and Tech. Nigeria, where the voucher specimen was prepared and deposited. Samples were washed with running tap water, air dried for 12 days and grounded into powder using a mortar and pestle and stored in an air tight well labeled container. $100 \mathrm{~g}$ of the grounded sample was dissolved in $500 \mathrm{~mL}$ each of petroleum ether, methanol and distilled water for 48 hours, the samples were stored in the refrigerator and the extracts were filtered separately with Whatman filter paper No.1 to obtain filtrates which was subjected to further analysis.

Preliminary screening of bioactive chemicals

The screening covered the following parameters:

Tannins (Ferric chloride and Lead acetate test), flavonoids (Pew's, Shinoda and NaOH test), alkaloids (Iodine, 
Wanger's and Dragendroff's test), Phenols (Ellagic acid test), Saponins (foam test), Sterols (Salkowski test), Glycosides (Keller-Killani and conc. $\mathrm{H}_{2} \mathrm{SO}_{4}$ ), carbohydrates (Molisch's and Seliwanoff's test) and protein (Biuret test)

\section{Procedures}

Test for Tannins

Ferric chloride test

$2 \mathrm{ml}$ of test solution followed by addition of few drops of $5 \%$ ferric chloride solution. The formation of a blue colour indicates the presence of hydrolysable tannins (Kokate, 2005; Harbone, 1998).

Lead acetate test

$2 \mathrm{ml}$ of test solution in a test tube, a few drops of $10 \%$ lead acetate solution was added, a formation of a yellow or red precipitate indicated the presence of condensed tannins (Tease and Evans, 1985).

Test for Flavonoids

Pew's test

Zinc powder was added to $2 \mathrm{ml}$ of extract in a test tube followed by drop wise addition of conc. $\mathrm{HCl}$. The formation of purple red or cherry colour indicates the presence of flavonoids (Peach and Tracey, 1956).

Shinoda test

$2 \mathrm{ml}$ of the extract was added in the test tube with few fragments of magnesium metal followed by drop wise addition of conc. HCl. Formation of magentia colour indicates the presence of flavonoids (Kokate et al., 2001).

$\mathrm{NaOH}$ test

2-3 $\mathrm{ml}$ of the extract was put in a test tube and few drops of sodium hydroxide solution were added. Formation of intense yellow colour which becomes colourless on addition of few drops of dilute $\mathrm{HCl}$ indicates the presence of flavonoids (Khandewal, 2008).

Test for alkaloids

Iodine test

$3 \mathrm{ml}$ of extract was poured into a test tube, few drops of dilute iodine solution was added. Formation of a blue colour which disappears on boiling and reappears on cooling indicates the presence of alkaloids (Khandewal, 2008).

Wagner's test

2-3 $\mathrm{ml}$ of the extract was put in a test tube followed by few drops of Wagner's reagent. Formation of reddish brown precipitate indicates the presence of alkaloids (Kokate et al., 2001).

Dragendorff's test

2-3 $\mathrm{ml}$ of the extract was put in a test tube, a few drops of Dragendorff's reagent. The formation of an orange brown precipitate indicates the presence of alkaloids (Kokate et al., 2001).

Test for phenol

Ellagic acid test

$3 \mathrm{ml}$ of the extract was treated with few drops of $5 \%(\mathrm{w} / \mathrm{v})$ glacial acetic acid and $5 \%(\mathrm{w} / \mathrm{v}) \mathrm{NaNO}_{2}$ solution in a test tube. Formation of a muddy or niger brown coloration indicates the presence of phenol (Gibbs, 1974).

Test for Saponins

Foam test

$2 \mathrm{ml}$ of the extract was diluted with $20 \mathrm{ml}$ of distilled water; it was shaken in a graduated cylinder for 15 minutes. A 1 $\mathrm{cm}$ layer of foam indicates the presence of saponin (Kokate et al., 2001).

Test for Sterol

Salkowski's test

$2 \mathrm{ml}$ of the extract with $2 \mathrm{ml}$ of chloroform and $2 \mathrm{ml}$ conc. $\mathrm{H}_{2} \mathrm{SO}_{4}$ were added in a test tube and shaken well. Chloroform layer appeared red and acid layer showed greenish yellow fluorescence indicated the presence of sterols (Kokate et al., 2001).

Test for glycosides

Keller-Kiliani test

$3 \mathrm{ml}$ of the extract and glacial acetic acid were put in a test tube followed by one drop of $\mathrm{FeCl}_{3}$ and conc. $\mathrm{H}_{2} \mathrm{SO}_{4}$. Reddish brown appears at the junction of the two liquid layers and upper layer bluish green colour indicates the presence of glycosides (Kokate et al., 2001).

Concentrated $\mathrm{H}_{2} \mathrm{SO}_{4}$ test

$5 \mathrm{ml}$ of the test material was mixed with $2 \mathrm{ml}$ glycial acetic acid in a test tube, followed by the addition of one drop of 5 $\% \mathrm{FeCl}_{3}$ and conc. $\mathrm{H}_{2} \mathrm{SO}_{4}$. Formation of a brown ring indicates the presence of glycosides (Kokate et al., 2001).

Test for carbohydrates

Molisch's test

$2 \mathrm{ml}$ of extract in a test tube, add a few drops of $1 \%$ alpha-napthol followed by $2 \mathrm{ml}$ of conc. $\mathrm{H}_{2} \mathrm{SO}_{4}$. A reddish violet or purple ring indicates the presence of carbohydrates (Harbone, 1998).

Seliwanoff's test

$1 \mathrm{ml}$ of extract in a test tube was added to $3 \mathrm{ml}$ of Seliwanoff's reagent and it was heated on water bath for 10 minutes 
and cooled followed by $1 \%$ nitrate solution. A formation of red colour confirmed the presence of carbohydrates (Harbone, 1998; Kokate et al., 2001).

Test for protein

Biuret test

$3 \mathrm{ml}$ of extract was placed in a test tube followed with the additions 5 drops of melons reagent and $2 \mathrm{ml}$ of $10 \% \mathrm{NaOH}$ and mixed thoroughly. Purple or violet colour is an indication of the presence of protein (Harbone, 1998).

\begin{tabular}{|c|c|c|c|}
\hline \multicolumn{4}{|c|}{ Results } \\
\hline Test & Aqueous & Methanol & Petroleum ether \\
\hline \multicolumn{4}{|l|}{ (1)Test for tannins } \\
\hline Ferric chloride test & $+\mathrm{ve}$ & +ve & +ve \\
\hline Lead acetate test & $+\mathrm{ve}$ & $+\mathrm{ve}$ & $+\mathrm{ve}$ \\
\hline \multicolumn{4}{|l|}{ (2) Test for flavonoids } \\
\hline Pew's test & $+\mathrm{ve}$ & $+\mathrm{ve}$ & $+\mathrm{ve}$ \\
\hline Shinoda test & -ve & $+\mathrm{ve}$ & $+\mathrm{ve}$ \\
\hline $\mathrm{NaOH}$ test & -ve & +ve & $+\mathrm{ve}$ \\
\hline \multicolumn{4}{|l|}{ (3) Test for alkaloids } \\
\hline Iodine test & -ve & +ve & $-+\mathrm{ve}$ \\
\hline Wagner's test & -ve & +ve & +ve \\
\hline Dragendorff's test & -ve & +ve & $+\mathrm{ve}$ \\
\hline \multicolumn{4}{|l|}{ (4) Test for phenols } \\
\hline Ellagic acid test & $+\mathrm{ve}$ & + ve & $+\mathrm{ve}$ \\
\hline \multicolumn{4}{|l|}{ (5) Test for saponins } \\
\hline Foam test & -ve & -ve & -ve \\
\hline \multicolumn{4}{|l|}{ (6) Test for sterols } \\
\hline Salkowski's test & $+\mathrm{ve}$ & $+\mathrm{ve}$ & $+\mathrm{ve}$ \\
\hline (7) Test for glycosides & $+\mathrm{ve}$ & + ve & $+\mathrm{ve}$ \\
\hline Keller-Kiliani test & $+\mathrm{ve}$ & $+\mathrm{ve}$ & $+\mathrm{ve}$ \\
\hline Conc. $\mathrm{H}_{2} \mathrm{SO}_{4}$ test & $+\mathrm{ve}$ & + ve & $+\mathrm{ve}$ \\
\hline \multicolumn{4}{|l|}{ (8)Test for carbohydrates } \\
\hline Molisch's test & +ve & +ve & + ve \\
\hline Seliwanoff's test & $+\mathrm{ve}$ & +ve & $+\mathrm{ve}$ \\
\hline \multicolumn{4}{|l|}{ (9) Test for protein } \\
\hline Biuret test & +ve & +ve & $+\mathrm{ve}$ \\
\hline
\end{tabular}

+ve : positive; -ve : negetive

\section{Discussion}

Table 1 revealed the preliminary screening of the bioactive chemicals in Wild sunflower (Tithonia diversifolia) roots. The result revealed that the sample contains several phytochemicals (bioactive chemicals) such as: protein, carbohydrates, tannins, phenols, steroids, glycosides, saponins, alkaloids and flavonoids. Petroleum ether, methanol and distilled water (aqueous) were used for the extraction process, variations were observed in the extracts. The aqueous extract revealed the presence tannins, flavonoids, phenols, steroids, glycosides, carbohydrates and protein. Saponins are the only compounds not found in wild sunflower root extract but contrary to the results observed in petroleum ether and methanol solvents which follow similar pattern, their results showed that the sample contained tannins, saponins, flavonoids, phenols, steroids, glycosides, carbohydrates and protein.

Phytochemicals are primary (chlorophyll, protein and carbohydrates) and secondary compounds (alkaloids, flavonoids, tannins, terpenoids, phenolic compounds etc.) that occur naturally in plants that help them perform multiple biological activities such as: anti-inflammatory, antioxidant, antviral, antifungal, anti-allergic, antispasmodic, chemoprotective and hypolipidemic properties (Takeda et al., 2008; Varsha et al., 2013; Alagbe, 2019; Musa et al., 2020). Medicinal plants 
are also reservoirs of biologically active compounds with therapeutic properties that are used for the treatment of various ailments (Shittu and Alagbe, 2020; Dilfuza et al., 2015; Shittu et al., 2020). The variations in the phytochemicals in wild sunflower root could be attributed to the method or extraction process, species differences, age, location, soil type and harvesting regimen (Omolere and Alagbe, 2020; Alagbe et al., 2020). Alkaloids exhibit various pharmacological activities such as: antimicrobial, antispasmodic, analgesic and antibacterial activities (Olafadehan et al., 2020; Edeoga et al., 2006; Faizi et al., 2008). Saponins are generally known for their antibacterial and antifungal properties (Olaleye, 1997; Cheeke, 2000; Alagbe and Soares, 2018). Phenols are strong antioxidants that scavenge free radicals (Hollman, 2001). Flavonoids posses anti-inflammatory, anti-allergic, anti-thrombotic and vasoprotective properties (Chen et al., 2000; Saleem et al., 2005). Tannins are known to posses' antibacterial and antiviral activity (Adisa et al., 2010; Olafadehan et al., 2020; Oluwafemi et al., 2020). Proteins play a central role in cell growth and strengthening the immune system (Akubugwo et al., 2007). Carbohydrates serve as a source of energy to animals and they are produced by plants during photosynthesis (Vasudevan and Steekumari, 2007; Olatunji et al., 2016).

\section{Conclusion}

The extraction of wild sunflower roots using different solvent have shown that the plant is loaded with various bioactive chemicals or phytochemicals which are capable of performing physiological action on the body of animals. Each medicinal plant has its own nutrient compostion besides the pharmacological effects and it can used for the treatment of various ailments especially among rural dwellers.

\section{References}

1. Alagbe, J.O (2020). Chemical evaluation of proximate, vitamin and amino acid profile of leaf, stem bark and roots of Indigofera tinctoria. International Journal on Integrated Education. 3(10): 150-157.

2. Oluwafemi, R.A., Oluwayinka, E.O and Alagbe, J.O. (2020). Effect of dietary supplementation of neem oil (Azadirachtia indica) on the growth performance and nutrient digestibility of weaned rabbits. European Journal of Biotechnology and Bioscience. 8(5): 6-10.

3. Alagbe, J.O., Sharma, R., Eunice Abidemi Ojo, Shittu, M.D and Bello Kamoru Atanda (2020). Chemical evaluation of the proximate, minerals, vitamins and phytochemical analysis of Daniellia oliveri stem bark. International Journal of Biological, Physical and Chemical Studies, 2(1):16-22.

4. Akintayo Balogun Omolere. M and Alagbe, J.O (2020). Probiotics and medicinal plants in poultry nutrition: A review. United International Journal for Research and Technology, 2(1): 7-13.

5. Musa, B., Alagbe, J.O., Adegbite Motunrade Betty, Omokore, E.A. (2020). Growth performance, caeca microbial population and immune response of broiler chicks fed aqueous extract of Balanites aegyptiaca and Alchornea cordifolia stem bark mixture. United Journal for Research and Technology, 2(2):13-21.

6. Olafadehan, O.A., Oluwafemi, R.A and Alagbe, J.O. (2020). Carcass quality, nutrient retention and caeca microbial population of broiler chicks administered Rolfe (Daniellia oliveri) leaf extract as an antibiotic alternative. Journal of Drug Discovery. 14(33):146-154.

7. Alagbe, J.O., Shittu, M.D and Eunice Abidemi Ojo (2020). Prospect of leaf extracts on the performance and blood profile of monogastric - A review. International Journal of Integrated Education. 3(7): 122-127.

8. Alagbe, J.O., Shittu, M.D., Bamigboye, S.O and Oluwatobi, A.O. (2019). Proximate and mineral composition of Pentadiplandra brazzeana stems bark. Electronic Research Journal of Engineering, Computer and Applied Sciences. 1(2019): 91-99.

9. Oluwafemi, R.A., Isiaka Olawale and Alagbe, J.O. (2020). Recent trends in the utilization of medicinal plants as growth promoters in poultry nutrition- A review. Research in: Agricultural and Veterinary Sciences. 4(1): 5-11.

10. Alagbe, J.O. (2020). Effect of dietary supplementation of Cymbopogon citratus oil on the haematology and serum biochemical parameters of broiler chicks. Electronic Research Journal of Engineering, Computer and Applied Sciences. 2(2020): 127-141.

11. Alagbe, J.O and Adegbite Motunrade Betty (2019). Haematological and serum biochemical indices of starter broiler chicks fed aqueous extract of Balanites aegyptiaca and Alchornea cordifolia bark mixture. International Journal of Biological, Physical and Chemical Studies. 1(1): 8-15

12. Alagbe, J.O (2019). Proximate, mineral and phytochemical analysis of Piliostigma thonningii stems bark and roots. International Journal of Biological, Physical and Chemical Studies, 1(1): 1-7.

13. Omokore, E.O and Alagbe, J.O. (2019). Efficacy of dried Phyllantus amarus leaf meal as an herbal feed additive on the growth performance, haematology and serum biochemistry of growing rabbits. International Journal of Academic Research and Development. 4(3): 97-104.

14. Alagbe, J.O and Soares, D.M. (2018). Effects of feeding different levels of Azolla pinnata, Polyalthia longifolia, Tithonia diversifolia, Moringa olifera, Azadiracta indica leaf meal infusion as an organic supplement on the performance and nutrient retention of growing grass cutters. Greener Journal of Agricultural Sciences. 8(1):01-11.

15. Takeda, Y.M., Tomonari, S., Masuda, H., Otsuka, K and Ashurmetov, O.A. (2008). A new phenolic glycoside from an Uzbek medicinal plant (Organum tyttanthum). Journal of Medicinal Plant. 62:71-74. 
16. Varsha, S., Agrawal, R.C and Sonam, P. (2013). Phytochemical screening and determination of antibacterial and antioxidant potential of Glychrrhiza glabra root extracts. Journal of Environmental Research and Development. 7(4): 1552-1558.

17. Adisa, R.M., Choudhary, E.A., Adenoye, G.A. and Olorunsogo, O.O. (2010). Hypoglycaemic and biochemical properties of Cnestis ferruginea. Afr. J. Tradit. Complement Altern Med. 7: 185-194.

18. Cheeke, P. R. (2000). Actual and potential applications of Yucca schidigera and Quillaja saponaria saponins in human and animal nutrition. J Anim Sci. 77:1-10.

19. Chen, C. Y., Chang, F. R., Shih, Y. C., Hsieh, T. J., Chia, Y. C., Tseng, H. Y., et al (2000). Cytotoxic constituents of Polyalthia longifolia var. pendula. J. Nat. Prod. 63:1475-8.

20. Hollman, P.C. (2001). Evidence for health benefits of plant phenols: Local or systemic effects? J. Sci. Food Agric. 81: 842-852.

21. Vasudevan, M. D. and Sreekumari, S. (2007). Textbook of biochemistry for medical students. 5th Ed., Jaypee Brothers Medical Publishers (P) Ltd. New Delhi, India, pp. 283-287, 309-313,318-320, 322.

22. Edeoga, H. O., Omosun, G., Uche, L. C. (2006). Chemical composition of Hyptis sauveolens and Ocimum gratissium hybrids from Nigerian Medicinal plants. African Journal of Biotechnology, 5(10): 892-895.

23. Stafford, H. A. (1997). Roles of flavonoids in symbiotic and defence functions in legumes roots. The Botanical Review Interpreting Botanical Progress, pp.31.

24. Olaleye, M. T. (1997). The mineral elements proximate analysis, phytochemical screening and toxicants of vernonia amygelina (Etidot) and Marsdenia latifolia (Utasi)- unpublished, B. Sc. Project Biochemistry department, University of Uyo, Uyo.

25. Kokate CK, Purohit AP, Gokhale SB.(2001). Carbohydrate and derived Products, drugs containing glycosides, drugs containing tannin Hs, lipids and protein alkaloids. Text book of Pharmacognosy, 7, edition, 2: 133-166

26. Kokate, C.K. (1994). Practical Pharmacognosy, 4th ed., Vallabh Prakasan, Delhi, 107-111.

27. Khandelwa,1 K.R. (2008).Practical Pharmacognocy. 19th edition, Nirali Prakashan, Pune, p. 149-159.

28. Gibbs, R.D. (1974). Chemotaxonomy of Flowering Plants. Vol.1, McGill Queen's University Press, Montreal and London.

29. Treare GE, Evans WC. (1985). Pharmacognosy 17th edn, Bahiv Tinal, London, 1985, 149

30. Peach K andTracey M.V.(1956). Modern methods of plant analysis. Vol. 3, Springer Verlag, Berlin.

31. Shashank bhatt, Dr. Suresh Dhyani.(2012). Preliminary Phytochemical Screening of Ailanthus excelsa Roxb. Int. J. Curr. Pharma. Res. 4(1):87-89..

32. Alagbe, J.O. (2020). Performance, hematology and serum biochemical parameters of weaner rabbits fed different levels of fermented Lagenaria brevifora whole fruit extract. Advances in Research and Reviews, 2020, 1:5.

33. L.Kawini, M. Bora, S.N. Upadhyay, J. Hazra. "Pharmacological Profile of Tithonia diversifolia (Hemsl.) A. Gray: A Comprehensive Review". Journal of Drug Research in Ayurvedic Sciences", vol. 2, no. 3, pp. 183 187,2017

34. Akobundu IO, Agyakwa CW (1997). A Handbook of West African Weeds. International Institute of Tropical Agriculture (I.I.T.A.) Ibadan, Nigeria. 18: 76 - 79.

35. I.O. Oyewole, C.A. Ibidapo, D.O. Moronkola, A.O. Oduola, G.O. Adeoye, G.N. Anyasor, and J.A. Obansa. "Anti-malarial and repellent activities of Tithonia diversifolia (Hemsl.) leaf extracts". Journal of Medicinal Plant Research ,vol. 2, pp. 171-175, 2008

36. O.B. Umar, R.D. Alex, E.E. Obukohwo. "Phytochemical and proximate composition of Tithonia diversifolia (Hemsl.) A. Gray". Annals. Food Science and Technology, vol.16, pp. 195-200, 2015

37. A.M Tagne, F.Marino and M. Cosentino. "Tithonia diversifolia (Hemsl.) A. Gray as a medicinal plant: a comprehensive review of its ethnopharmacology, phytochemistry, pharmacotoxicology and clinical relevance", Journal of Ethnopharmacology, Volume 220, 28, Pages 94-116, June 2018.

38. K.S. Chukwuka, S. Ogunyemi, and I. Fawole. "Ecological distribution of Tithonia diversifolia (Hemsl). A. Gray-a new exotic weed in Nigeria". Journal of Biological Science, vol. 7, pp. 709-719, 2007

39. M.S.H.Wahyuningsih, A.W. Mahardika, B. Arief, and H. Muhammad. "Isolation and identification of potential cytotoxic compound from Kembang bulan (Tithonia diversifolia (Hemsl.) A Gray) leaves". International Journal of Pharmaceutical Pharmacy Science, vol. 7, pp. 298-301, 2015p

40. Robson Miranda da Gama, Marcelo Guimarães, Luiz Carlos de Abreu, José Armando-Junior. (2015). Phytochemical screening and antioxidant activity of ethanol extract of Tithonia diversifolia (Hemsl) A. Gray dry flowers. Asian Pac J Trop Biomed 2014; 4(9): 740-742.

41. Essiett, U. A. and Akpan, E. M. (2013). Proximate Composition and Phytochemical Constituents Of Aspilia africana (Pers) C. D. Adams and Tithonia diversifolia (Hemsl) A. Gray Stems (Asteraceae). Bulletin of Environment, Pharmacology, and Life Sciences, March 2013; 2(4): 33-37.

42. Olutobi O, Olasupo I (2012). Phytochemical Screening and the Phytotoxic Effect of Aqueous Extracts of Tithonia diversifolia (Hemsl) A. Gray. International Journal of Biology. 4(3): 97/

43. Martinez MJA, Lazaro RM, Del Olmo LMB, Benito PB (2008). Anti-infectious activity in the anthemideae tribe. In: Atta-ur (Ed.). Studies in Natural Products Chemistry, Vol. 35. Elsevier. pp. 445-516.

44. Doughari JH (2012). Phytochemicals: Extraction Methods, Basic Structures and Mode of Action as Potential 
Chemotherapeutic Agents. In: Rao, V. (Ed.), Phytochemicals- A Global Perspective of Their Role in Nutrition and Health, InTech, Shanghai. $538 \mathrm{pp}$.

45. Olatunji, A.K., Alagbe, J.O and Hammed, M.A. (2015). Effects of varying levels of Moringa olifera leaf meal on performance and blood profile of weaner rabbits. International Journal of Science and Research. 5(6):803806. 